\title{
HYIGIENE DAN SANITASI MAKANAN DI RUMAH SAKIT UMUM DAERAH Dr. A. DADI TJOKRODIPO BANDAR LAMPUNG
}

\author{
Dini Rasika Sani ${ }^{1)}$
}

\begin{abstract}
Abstrak
Hygiene adalah upaya kesehatan dengan cara memelihara dan melindungi kebersihan individu, misalnya mencuci tangan untuk melindungi kebersihan tangan, mencuci piring melindungi kebersihan piring, membuang bagian makanan yang rusak untuk melindungi keutuhan makanan secara keseluruhan. Sanitasi makanan adalah upaya-upaya yang ditujukan untuk kebersihan dan keamanan makanan agar tidak menimbulkan bahaya keracunan dan penyakit pada manusia.

Tujuan penelitian untuk mengetahui pengelolaan hygiene dan sanitasi makanan di RSUD dr. A. Dadi Tjokrodipo, meliputi pemilihan bahan makanan, penyimpanan bahan makanan, pengolahan makanan, penyimpanan makanan jadi, pengangkutan makanan, dan penyajian makanan.

Penelitian bersifat deskriptif, yaitu menggambarkan tentang pengelolaan hygiene dan sanitasi makanan yang meliputi pemilihan bahan makanan, penyimpanan bahan makanan, pengolahan makanan, penyimpanan makanan jadi/masak, pengangkutan makanan, dan penyajian makanan di RSUD dr. A. Dadi Tjokrodipo.

Hasil penelitian menyimpulkan bahwa pengelolaan hygiene dan sanitasi makanan di RSUD dr. A. Dadi Tjokrodipo sudah memenuhi syarat yaitu pemilihan bahan baku, pengangkutan makanan, penyajian makanan. Pengelolaan hygiene dan sanitasi makanan yang belum memenuhi syarat yaitu penyimpanan bahan makanan, pengolahan makanan dan penyimpanan makanan jadi.
\end{abstract}

Kata Kunci: Hygiene, sanitasi, makanan

1) Alumni Jurusan Kesehatan Lingkungan Poltekkes Kemenkes Tanjungkarang

\section{PENDAHULUAN}

Pengertian makanan menurut WHO adalah semua substansi yang dibutuhkan oleh tubuh tidak termasuk air, obat-obatan, dan substansisubstansi lain yang digunakan untuk pengobatan. Air tidak termasuk dalam makanan karena merupakan elemen yang vital bagi kehidupan manusia. Fungsi makanan adalah sebagai sumber energi, sebagai zat pembangunan, memelihara dan memperbaiki jaringan tubuh yang sudah tua, serta, sebagai zat pengatur karena makanan turut serta mengatur proses alami, kimia, dan proses faal dalam tubuh (Chandra, 2006).

Makanan merupakan salah satu bagian yang penting untuk kesehatan manusia mengingat setiap saat dapat saja terjadi penyakit-penyakit yang diakibatkan oleh makanan. Kasus penyakit bawaan makanan (foodborne disease) dapat dipengaruhi oleh berbagai faktor. Faktorfaktor tersebut antara lain, kebiasaan mengolah makanan secara tradisional, penyimpanan dan penyajian yang tidak bersih, dan tidak memenuhi persyaratan sanitasi (Chandra, 2006).

Pengelolaan makanan yang baik dan benar pada dasarnya adalah mengelola makanan berdasarkan kaidah-kaidah berdasarkan prinsip hygiene dan sanitasi makanan. Prinsip-prinsip sanitasi makanan adalah teori praktis tentang pengetahuan, sikap dan perilaku manusia dalam menaati azas kesehatan (health), azaz kebersihan (cleanliness) dan azas keamanan (security). Proses pengolahan makanan dilakukan melalui beberapa tahapan pengolahan mulai dari penerimaan bahan mentah, pencucian, peracikan, pemasakan sampai menjadi makanan yang siap santap. Dengan pengolahan makanan yang baik dan benar akan menghasilkan makanan yang bersih, sehat, amat dan bermanfaat serta tahan lama (Dinkes Provinsi Lampung, 2004).

Pengelolaan makanan harus menerapkan prinsip higiene sanitasi makanan mulai dari pemilihan bahan makanan, penyimpanan bahan makanan, pengolahan makanan, penyimpanan 
makanan jadi, pengangkutan makanan, dan penyajian makanan (Permenkes 1096, 2011).

Rumah sakit di Indonesia berjumlah 2.601 yang di klasifikasikan menjadi 2.045 adalah rumah sakit umum dan 556 adalah rumah sakit khusus. Jumlah rumah Sakit di Provinsi Lampung terdapat 64 rumah sakit, diantaranya 46 rumah sakit umum dan 18 rumah sakit khusus (Ditjend Pelayanan Kesehatan Kemenkes RI, 2017). Rumah Sakit Umum Daerah (RSUD) dr. A. Dadi Tjokrodipo Bandar Lampung merupakan rumah sakit tipe $\mathrm{C}$ yang beralamat di Jl.Basuki Rachmad No.73 Kec. Teluk Betung Utara Kota Bandar Lampung. RSUD dr. A. Dadi Tjokrodipo Bandar Lampung memiliki 80 tempat tidur dari 109 tempat tidur yang direncanakan.

Berdasarkan hasil studi pendahuluan diketahui bahwa pengelolaan hygiene sanitasi belum sesuai dengan ketetapan yang berlaku, antara lain suhu penyimpanan bahan makanan, dinding yang terkena percikan air tidak dilapisi dengan bahan kedap air, tidak ada jalur khusus dalam pengangkutan makanan, serta penjamah makanan belum memiliki sertifikasi kesehatan dan belum melakukan pemeriksaan kesehatan secara berkala. Penelitian bertujuan untuk mengetahui pelaksanaan pengelolaan hygiene dan sanitasi makanan di RSUD dr. A. Dadi Tjokrodipo Bandar Lampung.

\section{METODE}

Penelitian ini bersifat deskriptif, yaitu menggambarkan tentang pengelolaan hygiene dan sanitasi makanan di RSUD dr. A. Dadi Tjokrodipo Bandar Lampung. Penelitian dilaksanakan pada bulan Maret-Mei 2018. Subyek penelitian adalah seluruh tahapan pengelolaan hygiene dan sanitasi makanan, yaitu pemilihan bahan makanan, penyimpanan bahan makanan, pengolahan makanan, penyimpanan makanan jadi/masak, pengangkutan makanan, dan penyajian makanan.

Data dikumpulkan melalui observasi menggunakan checklist pada setiap tahap pengelolaan hygiene dan sanitasi makanan. Wawancara menggunakan daftar pertanyaan untuk memperoleh informasi dari kepala sanitasi, dan tenaga pengelola makanan.

Data yang diperoleh selanjutnya dianalisis berdasarkan Peraturan Menteri Kesehatan RI Nomor 1204/Menkes/SK/X/2004 tentang Persyaratan Kesehatan Lingkungan Rumah Sakit. Data disajikan dalam bentuk tabel dan narasi. kemudian

\section{HASIL}

\section{Pemilihan Bahan Baku}

Berdasarkan Tabel 1 terlihat bahwa pembelian bahan makanan di RSUD dr. A Dadi Tjokrodipo dari tempat yang sudah memiliki surat izin resmi, kualitas bahan makanan yang digunakan dalam keadaan baik, yaitu tidak berubah warna dan rasa, tidak rusak, tidak berjamur dan tidak bernoda. Bahan makanan diperiksa secara fisik, bahan makanan kemasan mempunyai label dan merek, dan tidak menggunakan bahan makanan tambahan seperti bahan pewarna, pengawet, dan pemanis buatan.

Pembelian bahan makanan kering di RSUD dr. A Dadi Tjokrodipo dilakukan satu bulan sekali sedangkan untuk pembelian bahan makanan basah seperti sayur, buah, ayam, daging, telur dilakukan sehari sekali. Bahan makanan yang dipilih dalam kondisi baik dan memenuhi syarat hygiene sanitasi makanan.

Tabel 1. Pemilihan Bahan Baku

\begin{tabular}{llc}
\hline No & Komponen Pengamatan & Penilaian \\
\hline 1 & Pembelian bahan makanan ditempat yang resmi & Ya \\
2 & Kualitas bahan makanan dalam keadaan baik & Ya \\
3 & Bahan makanan diperiksa secara laboratorium minimal 1 bulan sekali & Tidak \\
4 & Bahan makanan kemasan (terolah) mempunyai label, merek, dan dalam keadaan baik & Ya \\
5 & Bahan makanan tambahan (bahan pewarna, pengawet, pemanis buatan harus sesuai dengan & Ya \\
& ketentuan & \\
\hline
\end{tabular}

\section{Penyimpanan Bahan Baku}

Dari Tabel 2 terlihat bahwa tempat penyimpanan bahan basah terpelihara dan dalam keadaan bersih, terlindung dari debu, bahan kimia berbahaya, serangga dan hewan lainnya, serta menggunakan prinsip First In
First Out (FIFO). Bahan makanan yang cepat rusak disimpan dalam lemari pendingin, dan bahan makanan kering disimpan di tempat yang kering dan tidak lembap.

Semua bahan makanan berada di bagian yang tinggi, tidak diletakkan di bawah saluran 
air atau limbah, tidak ada drainase di sekitar gudang. Suhu gudang bahan makanan kering $29,8^{\circ} \mathrm{C}$, dan kelembapan di ruangan sekitar 50$60 \%$.

Bahan makanan yang datang dari pemasok kemudian dipilah dan ditimbang di ruang penerimaan. Bahan makanan yang bisa dicuci masuk ke ruang cuci, kemudian disimpan di gudang penyimpanan makanan. Bahan makanan kering langsung masuk ke gudang penyimpanan makanan kering.

Penyimpanan bahan makanan basah di lemari pendingin. Dilakukan pemisahan tempat penyimpanan bahan makanan siap olah, bahan makanan lebih dari 1 minggu, bahan makanan setengah jadi, makanan khusus puding, dan penyimpanan buah dan sayur. Bahan makanan kering disimpan di rak-rak terbuka yang terbuat dari alumunium.

Tabel 2. Penyimpanan Bahan Baku

\begin{tabular}{llc}
\hline No & Komponen Pengamatan & Penilaian \\
\hline 1 & $\begin{array}{l}\text { Tempat penyimpanan bahan makanan harus selalu terpelihara dan dalam keadaan bersih, } \\
\text { terlindung dari debu, bahan kimia berbahaya, serangga dan hewan lain }\end{array}$ & Ya \\
2 & $\begin{array}{l}\text { Penyimpanan harus memperhatikan prinsip first in first out (FIFO) dan first expired first out } \\
(F E F O)\end{array}$ & Ya \\
3 & $\begin{array}{l}\text { Tempat atau wadah penyimpanan } \\
\text { a. Bahan makanan yang cepat rusak disimpan dalam lemari pendingin } \\
\text { b. Bahan makanan kering disimpan ditempat yang kering dan tidak lembab }\end{array}$ \\
4 & $\begin{array}{l}\text { Bahan makanan tidak diletakkan di bawah saluran/pipa air (air bersih maupun air limbah) } \\
\text { untuk menghindari terkena bocoran }\end{array}$ & Ya \\
5 & Tidak ada drainase di sekitar gudang. & Ya \\
6 & Suhu gudang bahan makanan kering dan kaleng dijaga kurang dari $22^{\circ} \mathrm{C}$. & Ya \\
7 & Memperhatikan suhu dalam penyimpanan bahan makanan & Tidak \\
8 & Kelembapan penyimpanan dalam ruangan $80-90 \%$. & Ya \\
9 & $\begin{array}{l}\text { Penyimpanan bahan makanan olahan pabrik, Makanan dalam kemasan tertutup disimpan } \\
\text { pada suhu } \pm 10^{\circ} \mathrm{C}\end{array}$ & Tidak \\
10 & Yarak bahan makanan dengan lantai $15 \mathrm{~cm}$ & Ya \\
11 & Jarak bahan makanan dengan dinding $5 \mathrm{~cm}$ & Ya \\
12 & Jarak bahan makanan dengan langit-langit $60 \mathrm{~cm}$ & Ya \\
\hline
\end{tabular}

\section{Pengolahan Makanan}

Berdasarkan Tabel 4 terlihat bahwa tempat pengolahan makanan memiliki konstruksi yang kuat dan bersih, pembuangan air limbah tidak menimbulkan sarang serangga dan tikus. Lantai kedap air, rata, tidak retak, tidak licin, dan mudah dibersihkan. Dinding ruangan rata, tidak lembab, mudah dibersihkan, berwarna terang, permukaan dinding yang selalu kena percikan air dilapisi dengan bahan kedap air setinggi 1 meter dari lantai.

Langit-langit ruangan berwarna terang, menutupi seluruh atap bangunan, permukaan rata, mudah dibersihkan, dan tidak menyerap air. Pintu membuka ke arah luar dan intensitas cahaya \pm 223 Lux. Ruang pengolahan makanan tidak berhubungan langsung dengan jamban/toilet, peturasan dan kamar mandi. Terdapat meja kerja, lemari sebagai tempat penyimpanan bahan, pembersihan dilakukan setiap sebelum dan sesudah kegiatan pengolahan makanan, dan terdapat cerobong asap.

Peralatan masak yang digunakan dalam pengolahan makanan tidak melepaskan zat beracun, tidak patah dan kotor, lapisan terbuka tidak terlarut dalam asam atau basa atau garamgaram. Peralatan dicuci segera setelah digunakan, disimpan dalam keadaan kering pada rak yang terlindung dari vektor.

Seluruh penjamah makanan berjumlah 8 orang (4 sebagai juru masak dan 4 sebagai pramusaji), sehat dan bebas dari penyakit menular. Namun penjamah makanan belum melakukan pemeriksaan kesehatan secara berkala, minimal 2 kali setahun. Penjamah makanan telah dilengkapi dengan pakaian kerja (celemek, topi, dan sarung tangan plastik), namun tidak menggunakan masker. Penjamah makanan selalu mencuci tangan menggunakan sabun sebelum bekerja dan setelah keluar dari toilet. 
Tabel 4. Pengolahan Makanan

\begin{tabular}{|c|c|c|}
\hline No & Komponen Pengamatan & Penilaian \\
\hline \multirow[t]{13}{*}{ A } & Tempat pengolahan makanan (dapur) & \\
\hline & a. Pembuangan air limbah tidak menimbulkan sarang serangga da jalan masuknya tikus & $\mathrm{Ya}$ \\
\hline & b. Kontruksi kokoh, aman, selalu dalam keadaan bersih & Ya \\
\hline & c. Lantai kedap air, rata, tidak retak, tidak licin, mudah dibersihkan & Ya \\
\hline & $\begin{array}{l}\text { d. Dinding rata, tidak lembap, mudah dibersihkan, berwarna terang, permukaan dinding } \\
\text { yang selalu kena percikan air dilapisi dengan bahan kedap air setinggi } 2 \mathrm{~m} \text { dari lantai } \\
\text { (permukaan halus, tidak menahan debu, berwarna terang), sudut dinding dengan lantai } \\
\text { conus }\end{array}$ & Ya \\
\hline & $\begin{array}{l}\text { e. Langit-langit berwarna terang, menutupi seluruh atap bangunan, permukaan rata, mudah } \\
\text { dibersihkan, tidak menyerap air, tinggi langit-langit minimal } 2,4 \mathrm{~m} \text { dari lantai }\end{array}$ & Ya \\
\hline & $\begin{array}{l}\text { f. Pintu membuka kearah keluar dan dapat menutup sendiri serta dilengkapi peralatan anti } \\
\text { serangga }\end{array}$ & Ya \\
\hline & g. Intensitas cahaya minimal 200 lux & \\
\hline & h. Terdapat ventilasi & Ya \\
\hline & $\begin{array}{l}\text { i. Ruang pengolahan makanan tidak berhubungan langsung dengan jamban/toilet, peturasan } \\
\text { dan kamar mandi }\end{array}$ & Ya \\
\hline & j. Minimal terdapat meja kerja, lemari sebagai tempat penyimpanan bahan dan makan jadi & Ya \\
\hline & k. Sebelum dan sesudah kegiatan pengolahan makanan selalu dibersihkan dengan antiseptic & $\mathrm{Ya}$ \\
\hline & 1. Asap dikeluarkan melalui cerobong yang dilengkapi dengan sungkup asap & Ya \\
\hline \multirow[t]{6}{*}{$\mathbf{B}$} & Peralatan masak & \\
\hline & a. Peralatan masak tidak boleh melepaskan zat beracun kepada makanan & Ya \\
\hline & b. Peralatan masak tidak boleh patah dan kotor & Ya \\
\hline & $\begin{array}{l}\text { c. Lapisan terbuka tidak terlarut dalam asam atau basa atau garam-garam yang lazim } \\
\text { dijumpai dalam makanan }\end{array}$ & Ya \\
\hline & d. Peralatan dicuci segera setelah digunakan, selanjutya didesinfeksi dan dikeringkan & Ya \\
\hline & $\begin{array}{l}\text { e. Peralatan yang sudah bersih harus disimpan dalam keadaan kering dan disimpan pada rak } \\
\text { terlindung dari vektor }\end{array}$ & Ya \\
\hline \multirow[t]{5}{*}{$\mathbf{C}$} & Penjamah makanan & \\
\hline & a. Harus sehat dan bebas dari penyakit menular & Ya \\
\hline & $\begin{array}{l}\text { b. Secara berkala minimal } 2 \text { kali setahun diperiksa kesehatannya oleh dokter yang } \\
\text { berwenang }\end{array}$ & Tidak \\
\hline & c. Harus menggunakan pakaian kerja dan perlengkapan pelindung pengolahan dapur & Tidak \\
\hline & $\begin{array}{l}\text { d. Selalu mencuci tangan menggunakan sabun sebelum bekerja atau setelah keluar dari } \\
\text { kamar kecil }\end{array}$ & $\mathrm{Ya}$ \\
\hline
\end{tabular}

\section{Penyimpanan makanan jadi/masak}

Penyimpanan makanan jadi dalam wadah atau kemasan tertutup, dan segera disajikan kepada pasien. Belum dilakukan pemeriksaan bakteriologi secara berkala untuk mengetahui cemaran mikroba pada makanan. Tidak dilakukan penyimpanan makanan jadi. Seluruh makanan yang telah dimasak, dimasukkan ke dalam wadah tertutup, kemudian dimasukkan ke dalam plato untuk disajikan kepada pasien, dalam kondisi tertutup.

\section{Pengangkutan makanan}

Pengangkutan makanan jadi menggunakan kereta dorong (troli) khusus makanan yang bersih dan tertutup, dan pengisian kereta dorong tidak penuh. Pengangkutan makanan dan pengangkutan plato kotor ke dapur sudah menggunakan jalur khusus, pintu masuk makanan yang akan disajikan kepada pasien dengan pintu masuk plato kotor terpisah. Namun belum terdapat jalur khusus yang terpisah untuk mengangkut barang kotor pada pengangkutan makanan ke ruang pasien. Kereta untuk membawa makanan berbeda dengan kereta pengangkut plato kotor.

Pendistribusian makanan di RSUD Dr. A Dadi Tjokrodipo dilakukan 3 kali dalam sehari, yaitu pagi pada pukul $07.00 \mathrm{WIB}$, siang pada pukul 11.30 WIB, dan sore pada pukul 05.00 WIB. Pengangkutan makanan dengan pengangkutan barang kotor dilakukan pada waktu yang berbeda.

\section{Penyajian makanan}

Hasil pengamatan yang dilakukan, peralatan untuk menyajikan makanan di RSUD Dr. A Dadi Tjokrodipo dalam keadaan bersih. Makanan disajikan dalam wadah tertutup dan dalam keadaan hangat. Namun belum dilakukan 
pemeriksaan angka kuman pada makanan jadi untuk mengetahui cemaran mikroba.

\section{PEMBAHASAN}

\section{Pemilihan Bahan Baku}

Menurut Peraturan Menteri Kesehatan RI nomor 1204 tahun 2004, pembelian bahan makanan sebaiknya di tempat resmi dan berkualitas, bahan makanan yang diolah harus mempunyai label dan merek serta dalam keadaan baik. Hasil penelitian mendapatkan bahwa pemilihan bahan makanan yang dilakukan RSUD Dr. A Dadi Tjokrodipo sudah baik, dan telah sesuai dengan peraturan yang berlaku.

Pada tahapan pemilihan bahan baku, terdapat satu komponen yang belum dilakukan, yaitu pemeriksaan laboratorium minimal satu bulan sekali. Pemeriksaan laboratorium bertujuan untuk mengetahui kandungan gizi, serta cemaran kimia, mikroba, dan parasit. Perlu peningkatan kualitas pelayanan higiene sanitasi makanan melalui pemeriksaan bahan makanan secara rutin dengan melibatkan pemasok bahan makanan.

\section{Penyimpanan Bahan Baku}

Secara umum, penyimpanan bahan makanan di RSUD Dr. A Dadi Tjokrodipo telah sesuai dengan Peraturan Menteri Kesehatan RI nomor 1204 tahun 2004. Namun, terdapat dua komponen yang belum dilaksanakan seca baik, yaitu pengaturan suhu dan kelembaban pada gudang bahan makanan kering dan kaleng. Hasil pengukuran suhu gudang bahan makanan kering sebesr $29,8^{\circ} \mathrm{C}$, dan kelembapan di ruangan sekitar 50-60\%. Menurut Permenkes RI nomor 1204 tahun 2004, suhu gudang penyimpanan bahan makanan kering dan kaleng adalah $22^{\circ} \mathrm{C}$, dan kelembaban $80-90 \%$.

Pengaturan suhu dan kelembaban pada gudang penyimpanan makanan kering bertujuan untuk menghindari berkembangnya mikroba dan jamur pada bahan makanan. Salah satu upaya yang dapat dilakukan adalah dengan pemasangan Air Conditioner dengan pengaturan suhu $22^{\circ} \mathrm{C}$.

\section{Pengolahan Bahan Makanan}

Menurut Peraturan Menteri Kesehatan RI nomor 1204 tahun 2004, terdapat tiga faktor yang harus diperhatikan dalam pengolahan makanan, yaitu tempat pengolahan, peralatan yang digunakan, serta tenaga pengolah atau penjamah makanan. Berdasarkan hasil penelitian diketahui bahwa tempat pengolahan makanan di RSUD Dr. A Dadi Tjokrodipo telah memenuhi persyaratan kesehatan. Konstruksi ruangan pengolahan serta penangannya telah dilakukan dengan baik, seperti pembersihan dan penerangan. Terpenuhinya persyaratan kesehatan ruangan pengolahan makanan akan memperkecil peluang masuknya cemaran dari lingkungan ke dalam makanan.

Hasil penelitian juga mendapatkan bahwa peralatan makanan yang digunakan dalam megolah makanan telah memenuhi persyaratan kesehatan, yaitu bersih, kondisi baik, tidak melepaskan zat beracun, dan tidak melarut pada kondisi asam atau basa dari bahan makanan. Penanganan peralatan juga telah dilakukan dengan baik, yaitu selalu dicuci dan didesinfeksi setelah digunakan , serta disimpan pada tempat tertutup. Seluruh peralatan logam untuk pengolahan makanan, terbuat dari stainless stell yang bersifat food grade.

Namun pada faktor penjamah makanan, terdapat dua komponen yang belum memenuhi persyaratan, yaitu belum dilakukan pemeriksaan kesehatan secara berkala minimal 2 kali dalam setahun, serta petugas tidak menggunakan masker. Pemeriksaan kesehatan terhadap penjamah makanan bertujuan untuk mengetahui status kesehatan penjamah, terutama status carrier penyakit. Seseorang dikatakan carrier atau pembawa penyakit, jika di dalam tubuhnya ditemukan agent penyakit namun tidak menunjukkan gejala atau tandatanda sakit. Seorang penjamah makanan yang berstatus carrier dapat mencemari makanan sehingga terjadi penularan penyakit terhadap pasien. Sedangkan penggunaan masker pada saat mengolah makanan bertujuan menghindari masuknya droplets penjamah ke dalam makanan.

Perlu peningkatan kualitas pelayanan higiene sanitasi makanan melalui pemeriksaan kesehatan secara berkala terhadap seluruh penjamah makanan, serta mewajibkan penggunaan masker pada saat mengolah makanan.

\section{Penyimpanan Makanan Jadi/Masak}

Menurut Peraturan Menteri Kesehatan RI nomor 1204 tahun 2004, makanan yang akan disajikan harus dalam keadaan baik dan bebas dari mikroba penyebab penyakit (pathogent). Persyaratan kesehatan mengharuskan makanan bebas bakteri e.coli $(0 / 100 \mathrm{ml}$ sampel minuman/makanan). 
Dari hasil penelitian diketahui bahwa dalam pengelolaan makanan, tidak dilakukan penyimpanan makanan jadi. Seluruh makanan yang telah dimasak dimasukkan ke dalam wadah tertutup, kemudian dimasukkan ke dalam plato untuk disajikan kepada pasien secara tertutup dan dalam kondisi hangat. Namun, belum dilakukan pemeriksaan angka kuman pada makanan untuk mengetahui adanya cemaran mikrobilogis serta sebagai quality control dalam mengelolakan makanan. Perlu dilakukan pemeriksaan angka kuman pada makanan jadi secara berkala untuk menjamin tidak terjadinya cemaran mikrobiologi pada makanan, sekaligus sebagai quality control dalam mengelolakan makanan.

\section{Pengangkutan Makanan}

Hasil penelitian mendapatkan bahwa pengangkutan makanan dari bagian pengolahan ke ruang pasen telah dilakukan dengan baik. Seluruh makanan diangkut menggunakan kereta (troly) tertutup terbuat dari bahan food grade. Telah dilakukan juga pemisahan pengangkutan makanan dengan pengangkutan plato kotor. Selain waktu pengangkutan, pemisahan juga dilakukan dengan penggunaan kereta (troly) yang berbeda.

Namun belum terdapat jalur khusus yang terpisah untuk mengangkut barang kotor dan pengangkutan makanan ke ruang pasien. Upaya yang dilakukan saat ini adalah dengan melakukan pengaturan waktu pengangkutan, sehingga tidak terjadi pertemuan antara barang kotor dan makanan dalam sebuah jalur.

\section{Penyajian Makanan}

Berdasarkan hasil penelitian diketahui bahwa penyajian makanan telah dilakukan denganbaik, sesuai dengan peraturan kesehatan. Seluruh makanan disajikan dalam wadah tertutup dan dalam keadaan hangat. Peralatan yang digunakan terbuat dari bahan yang aman untuk makanan (foodgraede) dan tidak larut sehingga mencemari makanan.

Menurut Peraturan Menteri Kesehatan RI nomor 1204 tahun 2004, penyajian makanan harus terhindar dari pencemaran dan peralatan yang dipakai harus bersih dan aman untuk makanan. Makanan disajikan dalam wadah tertutup, dan penyajian dilakukan oleh penyaji yang sehat dan berpakain bersih.

\section{KESIMPULAN}

Secara umum, pengelolaan hygiene dan sanitasi makanan telah memenuhi persyaratan kesehatan. Terdapat beberapa komponen yang belum terpenuhi, yaitu pemeriksaan laboratorium untuk bahan makanan, pemeriksaan angka kuman pada alat masak, alat makan, dan makanan jadi, serta pemeriksaan kesehatan rutin terhadap penjamah makanan. Selain untuk mencegah terjadi penyebaran penyakit, pemeriksaan angka kuman pada makanan digunakan sebagai quality control dalam mengelolakan makanan.

\section{DAFTAR PUSTAKA}

Aswar, Azrul, 1979. Pengantar Ilmu Kesehatan Lingkungan. Jakarta : Mutiara Sumber Widya.

Chandra, Budiman, 2006. Pengantar Kesehatan Lingkungan. Jakarta : EGC.

Dinas Kesehatan Provinsi Lampung. 2004. Prinsip-Pengelolaan hygiene Dan Sanitasi Makanan. Lampung : Depkes Lampung.

Peraturan Menteri Kesehatan RI No.1204/MENKES/SK/X/2004.

Persyaratan Kesehatan Lingkungan Rumah Sakit.

Peraturan Menteri Kesehatan RI No.1405/MENKES/PER/XI/2006.

Pedoman Organisasi Rumah Sakit Di Lingkungan Departemen Kesehatan.

Peraturan Menteri Kesehatan RI No.1096/MENKES/PER/VI/2011. Higiene Sanitasi Jasaboga. 